\title{
Value Added Products from Agriculture: Extraction of Pectin from Pumpkin (Cucurbita maxima) Waste
}

\section{Sanadarani MDJC* and Prasadi VPN}

Department of Food Science and Technology, Faculty of Livestock Fisheries and Nutrition, Wayamba University of Sri Lanka, Sri Lanka

\begin{abstract}
Pectin is a complex hetero polysaccharide mainly found in the primary cell wall of dicotyledonous plants and it is extensively employed as a gelling agent, thickener, stabilizer and emulsifier in food industry. This study was designed to extract and characterize pectin from waste of Cucurbita maxima. Pectin was extracted separately from core, peel and whole fruit of Cucurbita maxima by the method of acid hydrolysis. Subsequently, extracted pectin was isolated from acid solution through ethanol precipitation. Extracted pectin was dried at $40 \pm 1^{\circ} \mathrm{C}$ overnight. Physiochemical properties and solubility of dried pectin were evaluated using different tests.

The highest yield was reported for the fresh pumpkin peel extracted using $0.1 \mathrm{~N}$ hydrochloric acid at $80 \pm 5^{\circ} \mathrm{C}, 1.25 \mathrm{pH}$ for 1 hour. In addition moisture content, ash content, crude fibre content, crude fat content, crude protein content and degree of esterification of extracted pectin were $4.53 \%$ (SD 1.24\%), 3.11 (SD 0.16\%), 4.47\% (SD 0.3\%), 3.22\% (SD 0.74\%), 1.97\% (SD $0.42 \%$ ) and 67.64 (SD 0.89), respectively. In conclusion, pectin extracted from pumpkin waste can be categorized as high methoxy pectin.
\end{abstract}

Keywords: Acid hydrolysis; High ethoxy pectin; Physiochemical; Pumpkin waste

\section{Introduction}

Fruits and vegetables are widely used as an excellent source of micro nutrients and phytochemicals. Annual production of fruit and vegetables in Sri Lanka is about 800,000 metric tons. Notably, there is a $30-40 \%$ postharvest loss of fruits and vegetables in Sri Lanka [1]. Waste materials of fruit and vegetables including trimmings, peelings, seeds and whole fruits can be used to produce value added ingredients such as dietary fiber, phenolic compounds, flavonoids and carotenoids. Dietary fiber rich in bio-active compounds can be isolated from fruit and vegetables. Preferably, they can be used in different food products in order to improve the textural and functional properties [2].

Waste disposal and recyclability have become a serious problem in Sri Lanka. It has been estimated that domestic and industrial waste of Sri Lanka is about 1 ton per day. Among that fruit and vegetable accounts for $35 \%$ and $45 \%$ respectively. Therefore, damaged, immature and over ripened fruits and vegetables are commonly found in waste materials. Furthermore, It has been estimated that $10 \%-20 \%$ of waste is produced per a day at Dambulla economic center [3]. There is a great potential to extract value added ingredients from fruit and vegetable waste. But fruit and vegetable waste is not commonly reused in Sri Lanka for extraction of different value added ingredients. So, these waste materials can be used to extract pectin. It is a highly economical and feasible method.

Pectin is a soluble dietary fiber which is widely used as a thickener and a stabilizer in jellies and jams. Moreover, it is used as a functional ingredient [2]. Pectin is a complex polysaccharide made out of $\mathrm{D}$-galacturonic acid, L-rhamnose, L-arabinose, and D-galactose. They are linked by a (14) linkages. According to FAO regulations, pectin must contain at least $65 \%$ galacturonic acid [4].

There are two types of pectin depending on their degree of methylation (DM), pectin is referred to as high methoxy pectin (DM $>50)$ or low methoxy pectin $(\mathrm{DM}<50)$. High methoxy pectin can form gels in an acidic medium ( $\mathrm{pH}$ 2.0-3.5) if sucrose is present at a concentration higher than 55 weight $\%$. Low methoxy pectin can form gels over a larger $\mathrm{pH}$ range (2.0-6.0) in the presence of a divalent ion, such as calcium. Pectin consumption has been exceeded 20,000 tons per a year [5]. Moreover, commercially pectin is extracted from apple pomace or citrus peel. Pectin content ranges from 20 to $40 \mathrm{~g} / 100 \mathrm{~g}$ on dry weight basis [6].

New pectin sources have been investigated in order to compensate domestic and regional demands [7]. Researchers have investigated sugar beet pulp, sunflower heads, potato fiber, onion skins, tobacco leaves, papaya, mango coffee and cocoa, cotton, passion fruit peel, buttercup squash fruit, sugar palm meat, banana peel, and mulberry branch bark as new sources of pectin [8].

Pumpkin also can be used as an alternative source for the extraction of pectin. It has been discovered that pumpkin pectin has unique structural and functional properties [9]. Therefore, an attempt was made to extract and characterize pectin from Pumpkin waste.

\section{Materials and Methods}

Waste materials of pumpkin were obtained from the Pannala market. Pre cleaned samples were weighed and ground in to fine particles prior to the extraction.100 g of ground sample of pumpkin waste was weighed in to a borosilicate beaker. Then $200 \mathrm{~mL}$ of $0.1 \mathrm{~N}$ hydrochloric acid or other acid was added in to sae and $\mathrm{Ph}$ was adjusted to 1.25 . Samples were heated to $80 \pm 5^{\circ} \mathrm{C}$ in a water bath for 60 minutes under continuous stirring. Then samples were cooled to $20^{\circ} \mathrm{C}$ and centrifugation was done at $6000 \mathrm{rpm}$ for 10 minutes. Supernatant

${ }^{*}$ Corresponding author: Sanadarani MDJC, Department of Food Science and Technology, Faculty of Livestock Fisheries and Nutrition, Wayamba University of Sri Lanka, Sri Lanka, Tel: 94372281 412; E-mail: jayanichathurika69@gmail.com

Received February 13, 2018; Accepted March 15, 2018; Published March 23, 2018

Citation: Sanadarani MDJC, Prasadi VPN (2018) Value Added Products from Agriculture: Extraction of Pectin from Pumpkin (Cucurbita maxima) Waste. J Food Ind Microbiol 4: 125. doi:10.4172/2572-4134.1000125

Copyright: () 2018 Sanadarani MDJC, et al. This is an open-access article distributed under the terms of the Creative Commons Attribution License, which permits unrestricted use, distribution, and reproduction in any medium, provided the original author and source are credited. 
was filtered through a muslin cloth. $400 \mathrm{~mL}$ of $95 \%$ ethanol was added to the supernatant in order to recover pectin. Sample was kept for 16 hours to precipitate pectin. Then centrifugation was done and precipitate was separated. $70 \%$ ethanol was added to the precipitate to purify extracted pectin. Recovered wet pectin was dried at $40^{\circ} \mathrm{C}$ for 48 hours and powdering was done.

Pectin yield was calculated on fresh weight basis. Moisture, crude fat, crude protein, crude fibre and ash content of pectin was determined by AOAC methods. Solubility of pectin in cold water, hot water, cold and hot alkali was evaluated [10].

\section{Results and Discussion}

Figure 1 illustrates the percentage yield of pectin from core, peel and whole fruit of Cucurbita maxima extracted using hydrochloric acid. The results revealed that pectin content of pumpkin peel $(2.908 \%)$ is higher than the pectin content of core and the whole fruit. Core has the lowest yield. Because pectin found in and between the cell walls as an integral structural component of cells which helps to give them rigidity. Hence the hard parts of fruits contain more pectin than the soft parts [11]. Proximate composition and physio chemical properties of pectin is shown in Table 1.

Moisture content of pumpkin pectin was in the acceptable range (below 12\%). These values were lower than the pectin extracted from lemon pomace [12]. Furthermore, Bhavya and Suraksha [10] also reported higher moisture content in pectin from Musa acuminata and citrus fruits. Moisture content of pectin is very important for the storage conditions and shelf life and for the functionality of pectin. Moisture content can affect for the rate of hydration of pectin in gelation.

Ash content of pumpkin pectin was lower than the ash content of commercial pectin. Low ash content is important for the gelation. Furthermore, ash content indicates about the mineral content. Higher mineral content interferes in gelation. Therefore, it is crucial to have lower ash content. The inorganic impurities in pectin are indicated

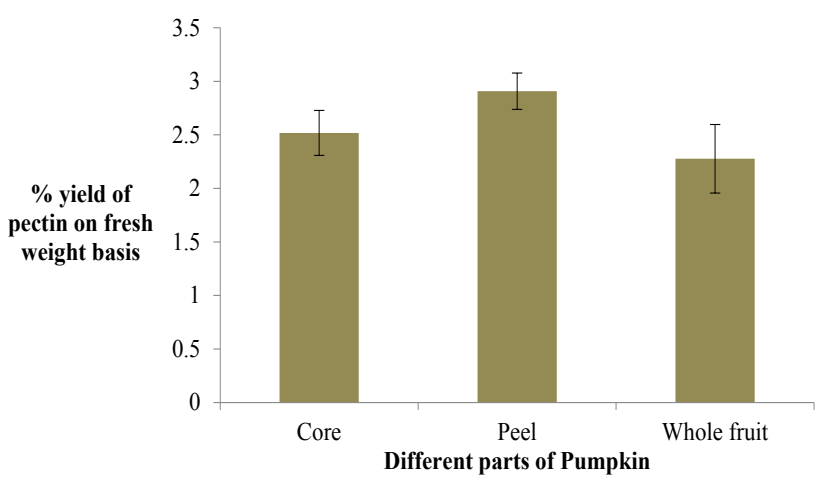

Figure 1: Yield of pectin from core, peel and whole fruit extracted using hydrochloric acid Error bars indicated the standard deviation.

\begin{tabular}{|c|c|c|}
\hline Characteristic & Commercial pectin & Pumpkin pectin \\
\hline Moisture content & $3.25 \pm 0.38$ & $4.53 \pm 1.24$ \\
\hline Ash content & $3.66 \pm 0.36$ & $3.11 \pm 0.16$ \\
\hline Crude fat content & $4.24 \pm 0.36$ & $3.22 \pm 0.74$ \\
\hline Crude fiber content & $3.94 \pm 0.43$ & $4.47 \pm 0.30$ \\
\hline Crude protein content & $2.33 \pm 0.39$ & $1.97 \pm 0.42$ \\
\hline Degree of esterification & $77.50 \pm 0.92$ & $67.64 \pm 0.89$ \\
\hline
\end{tabular}

Mean value from triplicate mean \pm standard deviation.

Table 1: Physiochemical and functional properties of pectin. by the ash content. Since low ash content is more favorable for gel formation, it could be reduced by washing with acidified alcohol. Low ash content was achieved using repeated washing with alcohol.

Crude fat content extracted pumpkin pectin was lower than the commercial pectin. It may be due to the difference in the raw material used for the extraction. Higher values were reported for pectin extracted from flavedo and albedo orange peels. Crude fiber content in extracted pectin was higher than the commercial pectin. It is due to difference in the raw material and also Cucurbita maxima is a vegetable which has higher fiber content. Crude protein content was lower than the commercial pectin; Vegetables are low in protein and other nitrogenous compounds. Lower crude protein contents were reported in pectin extracted from jackfruit waste

Degree of esterification of pumpkin pectin was $67.64 \%$. Therefore, it can be categorized as high methoxy pectin. Notably, pectin extracted from pumpkin has a great potential to utilize in jams and jellies as a gelling agent and a thickener. According to the results, Degree of esterification of extracted pectin is lower than the commercial pectin but it is higher than the values [13] for saba banana pectin. Similar values were reported for pumpkin pectin [14].

Solubility of pumpkin pectin and commercial pectin in water and alkali are presented in Table 2 .

\begin{tabular}{|c|c|c|}
\hline Characteristic & Commercial pectin & Pumpkin pectin \\
\hline Solubility in cold water & Partially soluble & Partially soluble \\
\hline Solubility in hot water & Soluble & Soluble \\
\hline Solubility in cold alkali & Partially soluble & Partially soluble \\
\hline Solubility in hot alkali & Partially soluble & Partially soluble \\
\hline
\end{tabular}

Table 2: Solubility of pectin.

According to the definition, pectin should be soluble in water. However, different factors can affect for the solubility of pectin. Insolubility of the extracted pectin is probably due to the presence of electrolytes in de-methylated pectic acid and the variation in the drying process of extracted pectin

\section{References}

1. Institute of Postharvest technology (2011) Annual report of institute of postharvest technology: Ministry of agriculture, Sri Lanka.

2. Yuliarti O, Matia-merino L, Goh KKT, Mawson J, Williams MAK, et al. (2015) Characterization of gold kiwifruit pectin from fruit of different maturities and extraction methods. Food Chem 166: 479-485.

3. United Nation Environment Program (2008) Report of Waste Quantification and Characterization. Matale: Sri Lanka, pp: 3-15.

4. Liew SQ, Chin NL, Yusof YA (2014) Extraction and Characterization of Pectin from Passion Fruit Peels. Ital Oral Surg. 2: 231-236.

5. Tang PY, Kek TS, Gan CZ, Hee CY, Chong CH, et al. (2011) Yield and Some Chemical Properties of Pectin Extracted from the Peels of Dragon Fruit. Phillipine Agric Sci 94: 307-311

6. Kulkarni SG, Vijayanand $P$ (2010) Effect of extraction conditions on the quality characteristics of pectin from passion fruit peel LWT. Food Sci Technol 43 1026-1031.

7. Koffi KL, Yapo BM, Besson V (2013) Extraction and characterization of gelling pectin from the peel of Poncirus trifoliata fruit. Agric Sci 4: 614-619.

8. Assoi S, Konan K, Walker LT, Holser R, Agbo GN, et al. (2014) Functionality and yield of pectin extracted from Palmyra palm (Borassus aethiopum Mart) fruit. LWT. Food Sci Technol 58:214-221.

9. Yoo S, Lee BH, Lee H, Bae Y, Lee HG, et al. (2012) Structural Characteristics of Pumpkin Pectin Extracted by Microwave Heating. J Food Sci 77: 1169-1173. 
Citation: Sanadarani MDJC, Prasadi VPN (2018) Value Added Products from Agriculture: Extraction of Pectin from Pumpkin (Cucurbita maxima) Waste. J Food Ind Microbiol 4: 125. doi:10.4172/2572-4134.1000125

Page 3 of 3

10. Bhavya DK, Suraksha R (2015) Value Added Products from Agriculture : Extraction of Pectin from Agro Waste Product Musa Acuminata and Citrus Fruit. Res. J Agri and Forestry Sci 3: 13-18.

11. Begum R, Aziz MG, Uddin MB, Yusof YA (2014) Characterization of Jackfruit (Artocarpus heterophyllus) Waste Pectin as Influenced by Various Extraction Conditions Agriculture and Agricultural Science Procedia. 2: 244-251.

12. Azad AKM, Ali MA, Akter S, Rahman J, Ahmed M (2014) Isolation \& characterization of pectin extracted from lemon pomace during ripening. J Food Nutr Sci 2: 30-35.

13. Israel-Castillo KAT, Baguio SF, Disanta MDB, Lizardo RCM, Dizon El, et al. (2015) Extraction and characterization of pectin from Saba banana pee wastes : A preliminary study. Int Food Res J 22: 202-207.

14. Liu Y, Shi J, Langrish TAG (2006) Water-based extraction of pectin from flavedo and albedo of orange peels. Chem Eng J 120: 203-209. 